\title{
Genetic Assessment of Three Colour Variants of African Yam Bean[Sphenostylis Stenocarpa] Commonly Grown in the Midwestern Region of Nigeria
}

\author{
Beckley Ikhajiagbe ${ }^{1, *}$, Joseph Kwesi Mensah ${ }^{2}$ \\ ${ }^{1}$ Dept. of Plant Biology and Biotech., University of Benin, Benin City \\ ${ }^{2}$ Dept. of Botany, Ambrose Alli University, Ekpoma
}

\begin{abstract}
Three varieties of African yam bean (Sphenostylis stenocarpa) were collected from six different locations in Edo State, Nigeria (Ekpoma, Benin City, Auchi, Igueben, Igbanke and Sabongida Ora). These seeds were then characterized based on seed colour into black, brown, and light grey. The seeds were screened in the field for agronomic and yield associated characters as well as chemical composition of the seeds. Considerable variations were observed in both agronomic and yield associated characters like shoot height, leaf area, grain yield and total ash content of the seeds. The black colour variant was significantly $(\mathrm{p}<0.05)$ highest in grain yield per hectare $(1542.28 \mathrm{~kg} / \mathrm{ha})$ compared to both brown variant $(1304.23 \mathrm{~kg} / \mathrm{ha})$ and the light grey type $(1259.97 \mathrm{~kg} / \mathrm{ha})$.
\end{abstract}

Keywords African Yam Bean, Agronomy, Heritability, Sphenostylis Stenocarpa

\section{Introduction}

Nigeria, like many third world countries is a food deficit country especially with the increasing population growth. Most rural communities cannot afford animal proteins and over three million children lack sufficient proteins within the last decade, and therefore suffer grossly retarded physical growth and development. Protein deficiencies also directly or indirectly affect the health and economic productivity of adult populations[1]. With the ever increasing population pressure and fast depletion of natural resources, it has become necessary to explore the possibilities of exploiting new plant resources to meet the growing needs of the human society, which incidentally has depended only on a small fraction of plant resources comprising less than 30 crops; among which is the African yam bean, a leguminous crop[2]. The African yam bean[Sphenostylis stenocarpa (Hochst. Ex A. Rich) Harms] is a climbing legume adapted to lowland tropical conditions. It is one of the lesser-known legumes[3, $4,5]$ and widely cultivated in the southern parts of Nigeria. The legumes are a good source of dietary protein[6]. They are cheaper than animal products such as meat, fish, poultry, egg - therefore they are consumed worldwide as a major source of cheap protein and especially in the developing or poor countries where consumption of animal protein may be

* Corresponding author:

ikhaj@yahoo.com (Beckley Ikhajiagbe)

Published online at http://journal.sapub.org/ijmb

Copyright (C) 2012 Scientific \& Academic Publishing. All Rights Reserved limited as a result of economic, social, cultural or religiousfactors[7]. Global food security however is becoming shaky with increasing dependence on a few major staple crops. This has resulted in an alarming reduction not only in crop diversity but also in the variability within crops. This therefore emphasizes the need for the collection and conservation of diversity within species. Usually when this done, there is the possibility for stockpiling crops of converse characteristics - for example, stockpiling low yielding varieties with high yielding ones.

\section{Objectives}

Biodiversity of species assures their evolutionary continuity. The collection and conservation of diversity within species is a safeguard against the loss of germplasm. They provide a buffer against environmental threats and assure continual and sustainable productivity. This is particularly achievable when the traits of these diverse species are documented as well. In Edo State, for example, a visit round markets in the areas chosen for study (Auchi, Benin City, Ekpoma, Igbanke, Igueben, and Sabongida Ora) show predominance of three colour variants of African yam bean - black, brown, and light grey colours. The present study therefore comparatively assesses some agronomic traits and chemical composition of seeds of three colour variants of African yam bean commonly grown in the Midwestern Region of Nigeria.

\section{Materials and Methods}




\subsection{Planting Materials}

Three varieties of African yam bean were collected from six different locations in Edo State (Auchi, Benin City, Ekpoma, Igbanke, Igueben, and Sabongida Ora). These towns are located in separate Local Government Areas of the State. The seed characteristics were measured and then characterized based on seed colour into black, brown, and light grey. Similar colour variants were pooled together from all the sources, and planted as described below.

\subsection{Germination Tests}

Germination tests were carried out on 2 disks of Whitman No.1 filter paper in $9 \mathrm{~cm}$ Petri dishes previously moistened with water. Twenty (20) seeds of the various variants were sown in each Petri dish. Seeds observed to have protrusions of the radicle were considered to have germinated $[8,9]$.

\subsection{Cultivation in Wooden Boxes}

Seeds were sterilized by immersing into $2 \%$ sodium hypochlorite for 7 minutes and rinsing repeatedly in distilled water[10]. Seeds were separately germinated in wooden boxes $(57 \mathrm{~cm} \times 41 \mathrm{~cm} \times 15 \mathrm{~cm})$ containing a mixture of top soil of known physicochemical property (Table 1) and organic manure in the ratio 2:3. Growth characteristics of the seedlings were taken into record for 3 days. Seedlings were transplanted after 14 days growth, into the field.

Table 1. Physicochemical Property of the Soil used for the Present Study

\begin{tabular}{cc}
\hline Soil Properties & Value \\
\hline $\mathrm{pH}$ & 5.68 \\
Carbon & $3.91 \%$ \\
Total N & $14.96 \mathrm{ppm}$ \\
$\mathrm{P}$ & $36.06 \mathrm{ppm}$ \\
$\mathrm{K}$ & $3.50 \mathrm{meq} / 100 \mathrm{~g}$ \\
$\mathrm{Ca}$ & $2.93 \mathrm{meq} / 100 \mathrm{~g}$ \\
$\mathrm{Mg}$ & $2.63 \mathrm{meq} / 100 \mathrm{~g}$ \\
$\mathrm{CEC}$ & $8.45 \mathrm{meq} / 100 \mathrm{~g}$ \\
Sand & $64.52 \%$ \\
Silt & $24.41 \%$ \\
Clay & $10.48 \%$ \\
\hline
\end{tabular}

\subsection{Cultivation in the Field}

The plot was cleared and tilled by properly mixing the soil. Mounds were made at a spacing of $60 \mathrm{~cm} \times 30 \mathrm{~cm}$ as proposed by Okeleye et al.[11]. Seedlings in the wooden boxes were then transplanted after 14 days growth, into the field of known soil characteristics (Table 2). Each mound received 2 seedlings, amounting to a mean of 55, 000 plant stands per hectare.

\subsection{Crop Husbandry}

The plot was weeded thrice before harvest. Although the plants were exposed to the prevailing weather condition (rainy season), water requirements by the crop were supplemented during very dry days by irrigating, each mound with $400 \mathrm{ml}$ distilled water beyond sunset. When plants were long enough, they were staked on bamboo poles.

\subsection{Parameters Determined}

Shoot height was measured from the soil level to the tip of the plant using a meter rule. Number of shoot branches and number of leaves were counted in situ. Leaf area was determined using the graph sheet method as described by Eze[12]. Chlorophyll content was measured using the method described by Holden[13]. Root length was measured with meter rule after irrigating and carefully uprooting the plants. The number of primary root branches, number of root nodules and weight of ten root nodules were determined. Plant dry weight was determined after drying to constant weight at $70^{\circ} \mathrm{C}$. Yield parameters were determined following the methods of IBPGR and ICRISAT[14]. Proximate and mineral analyses of dry harvested seeds were separately determined by using standard procedures of $\mathrm{AOAC}[15]$ and IITA[16]. Parameters include crude protein, crude fibre, ether extract, total ash and dry matter.

\subsection{Genetic Studies}

The genetic analysis was done on those parameters related to the variations in the colour of the beans. The mean squares at the treatment levels were taken as the phenotypic variance. Genotypic variance, which is the proportion of the phenotypic variance caused by variations in genes, the mean square at the error level, was subtracted from the corresponding phenotypic variance for all treatments used. The genetic parameters were as follows;

$$
\text { Heritability }(\%)=\frac{\delta^{2} \mathrm{~g}}{\delta^{\mathrm{pph}}} \times 100
$$

Where $\delta^{2} \mathrm{~g}=$ Genotypic variance, and $\delta^{2} \mathrm{ph}=$ Phenotypic variance

$$
\text { Genetic advance }=\frac{\delta^{2} \mathrm{~g}}{\delta \mathrm{ph}} \times \mathrm{k}
$$

Where $\mathrm{k}=2.06$ (selection differential at $10 \%$ ).

Genetic gain was calculated in terms of the genetic advance expressed as a percentage of the population mean.

\subsection{Experimental Design}

The experimental design adopted was the completely randomized design (CRD) following assumption of homogeneity of the experimental plot in use. As a result, treatments were randomized over the whole plot. Each treatment consisted of 20 replicates. The results were presented as mean values. Data was analyzed using the SPSS-16 Statistical Software. A probability of 0.05 was considered as significant.

\section{Results and Discussions}

The seed characteristics used in the present study were measured and then characterized based on seed colour into black, brown, and light grey. Table 2 shows the seed characteristics of African yam bean collected from Edo State. Significant variations among the seeds collected for the present study were in the colour; no significant differences were recorded in seeds size, similar to findings by Beridize $e t$ al.,[17]. 
Table 2. Seed characteristics of African yam bean collected from Edo State

\begin{tabular}{ccccc}
\hline Location & $\begin{array}{c}\text { colour } \\
\text { variants }\end{array}$ & $\begin{array}{c}100 \text { seed } \\
\text { wt }(\mathrm{g})\end{array}$ & $\begin{array}{c}\text { Breadth } \\
(\mathrm{mm})\end{array}$ & $\begin{array}{c}\text { Length } \\
(\mathrm{mm})\end{array}$ \\
\hline \multirow{2}{*}{ Auchi } & Black & $20.31^{\mathrm{b}}$ & $5.33^{\mathrm{a}}$ & $6.34^{\mathrm{b}}$ \\
& Brown & $23.11^{\mathrm{b}}$ & $5.06^{\mathrm{a}}$ & $6.31^{\mathrm{b}}$ \\
& Light Grey & $29.91^{\mathrm{a}}$ & $5.38^{\mathrm{a}}$ & $6.38^{\mathrm{b}}$ \\
Benin City & Black & $23.37^{\mathrm{b}}$ & $5.30^{\mathrm{a}}$ & $7.00^{\mathrm{ab}}$ \\
& Brown & $23.40^{\mathrm{b}}$ & $5.30^{\mathrm{a}}$ & $6.70^{\mathrm{b}}$ \\
Ekpoma & Light Grey & $22.83^{\mathrm{b}}$ & $5.30^{\mathrm{a}}$ & $6.00^{\mathrm{b}}$ \\
& Black & $23.67^{\mathrm{b}}$ & $5.60^{\mathrm{a}}$ & $8.00^{\mathrm{a}}$ \\
& Brown & $22.93^{\mathrm{b}}$ & $5.00^{\mathrm{a}}$ & $6.30^{\mathrm{b}}$ \\
Igbanke & Light Grey & $22.63^{\mathrm{b}}$ & $5.00^{\mathrm{a}}$ & $7.30^{\mathrm{ab}}$ \\
& Black & $23.40^{\mathrm{b}}$ & $5.30^{\mathrm{a}}$ & $7.30^{\mathrm{ab}}$ \\
& Brown & $23.47^{\mathrm{b}}$ & $5.30^{\mathrm{a}}$ & $7.00^{\mathrm{ab}}$ \\
Igueben & Light Grey & $22.67^{\mathrm{b}}$ & $5.70^{\mathrm{a}}$ & $7.00^{\mathrm{ab}}$ \\
& Black & $23.27^{\mathrm{b}}$ & $5.30^{\mathrm{a}}$ & $7.00^{\mathrm{ab}}$ \\
& Brown & $22.77^{\mathrm{b}}$ & $5.30^{\mathrm{a}}$ & $6.00^{\mathrm{b}}$ \\
Sabongida & Light Grey & $22.50^{\mathrm{b}}$ & $5.30^{\mathrm{a}}$ & $6.30^{\mathrm{b}}$ \\
Ora & Black & $23.73^{\mathrm{b}}$ & $5.30^{\mathrm{a}}$ & $7.00^{\mathrm{ab}}$ \\
& Brown & $22.90^{\mathrm{b}}$ & $5.00^{\mathrm{a}}$ & $6.00^{\mathrm{b}}$ \\
LSD & Light Grey & $22.63^{\mathrm{b}}$ & $5.70^{\mathrm{a}}$ & $6.00^{\mathrm{b}}$ \\
\hline & & 3.01. & 0.68. & 1.12. \\
\hline & & 23.47. & 5.30. & 6.66. \\
\hline
\end{tabular}

Values are means of 20 determinations. Means on the same column with similar alphabets do not differ significantly $(p<0.05)$ from each other.

Table 3 shows vegetative parameters of African yam bean. Germination percentage at 60 hours after planting (HAP), which ranged from $79.35 \%$ to $81.46 \%$, did not significantly $(\mathrm{p}<0.05)$ differ among the colour variants. Mean radicle length was $29.79 \mathrm{~mm}$ at $60 \mathrm{HAP}$, with no significant difference among the colour variants. Similarly, differences recorded for water imbibition rates at $60 \mathrm{HAP}$ were minimal and not significant. According to Valio[18] and Duke and Kakefuda[19], any differences recorded in water imbibition rates of cowpea may be attributed to thickness of seed coats. Significant variability in dry weight of germinated seeds at $60 \mathrm{HAP}$ was recorded. The brown seeds weighed $(0.131 \mathrm{~g})$ more than the other colour variants and the mean weight $(0.121 \mathrm{~g})$. Figures 1 and 2 both show the rate of germination percent and increase in radicle length for 60 hours. At 3 days after planting (DAP), mean percentage seedling emergence was $78.98 \%$, seedling height was $4.32 \mathrm{~cm}$, while dry weight of sprouted seedling was $0.23 \mathrm{~g}$. No significant variability in these parameters was recorded (Table 3). At 9 weeks after planting (WAP), significant differences in plant heights of the 3 variants were recorded. The black seed variant was highest $(130.36 \mathrm{~cm})$ and the brown variant being the least $(111.27 \mathrm{~cm})$. Ikhajiagbe et al.[9] previously reported that average shoot height of African yam bean was $107.32 \mathrm{~cm}$. Variability in leaflet area was also significant. Mean leaflet area was $51.42 \mathrm{~cm}^{2}$. no significant change was recorded in number of primary branches, stem width, total leaf number per plant, root length as well as root dry weight. Mean values of these parameters were $15.15,7.02 \mathrm{~mm}, 19.44,54.98 \mathrm{~cm}$, and $0.691 \mathrm{~g}$ respectively (Table 3 ). These were similar to findings by Ikhajiagbe et al.[9], who reported that stem girth, total leaf number per plant, root length and root dry weight of African yam bean were $7.28,18.13,57.41 \mathrm{~cm}$ and $0.655 \mathrm{~g}$ respectively.

Table 3. Comparative vegetative parameters of African yam bean

\begin{tabular}{cccccc}
\hline Parameters & \multicolumn{5}{c}{ Colour Variants } \\
& Black & Brown & $\begin{array}{c}\text { Light } \\
\text { Grey }\end{array}$ & $\begin{array}{c}\text { LSD } \\
(\mathrm{p}=0.05)\end{array}$ & Mean \\
\hline Germination percentage (\%) @ 60HAP & $79.35^{\mathrm{a}}$ & $81.46^{\mathrm{a}}$ & $80.52^{\mathrm{a}}$ & 4.25 & 80.44 \\
Radicle length (mm) @ 60HAP & $29.38^{\mathrm{a}}$ & $31.58^{\mathrm{a}}$ & $28.43^{\mathrm{a}}$ & 2.47 & 29.79 \\
Dry Wt.of germinated seed (g) @60HAP & $0.109^{\mathrm{b}}$ & $0.131^{\mathrm{a}}$ & $0.115^{\mathrm{b}}$ & 0.011 & 0.121 \\
Water imbibition (\%) @60HAP & $9.05^{\mathrm{a}}$ & $8.95^{\mathrm{a}}$ & $9.27^{\mathrm{a}}$ & 1.23 & 9.09 \\
Percentage emergence (\%) @3DAP & $78.62^{\mathrm{a}}$ & $80.13^{\mathrm{a}}$ & $78.10^{\mathrm{a}}$ & 6.17 & 78.98 \\
Seedling height (cm) @3DAP & $4.45^{\mathrm{a}}$ & $4.53^{\mathrm{a}}$ & $3.97^{\mathrm{a}}$ & 0.79 & 4.32 \\
Fresh Wt. of sprouted seedling @3DAP & $0.510^{\mathrm{a}}$ & $0.489^{\mathrm{a}}$ & $0.502^{\mathrm{a}}$ & 1.11 & 0.50 \\
Dry Wt.of sprouted seedling (g) @3DAP & $0.229^{\mathrm{a}}$ & $0.238^{\mathrm{a}}$ & $0.215^{\mathrm{a}}$ & 0.05 & 0.23 \\
Shoot height (cm) @9WAP & $130.36^{\mathrm{a}}$ & $111.27^{\mathrm{b}}$ & $123.42^{\mathrm{ab}}$ & 15.82 & 121.68 \\
No. of primary branches@9WAP & $16.03^{\mathrm{a}}$ & $14.48^{\mathrm{a}}$ & $14.93^{\mathrm{a}}$ & 3.71 & 15.15 \\
Stem width (mm) @9WAP & $7.06^{\mathrm{a}}$ & $7.43^{\mathrm{a}}$ & $6.57^{\mathrm{a}}$ & 1.08 & 7.02 \\
No. of leaves@9WAP & $20.11^{\mathrm{a}}$ & $18.49^{\mathrm{a}}$ & $19.71^{\mathrm{a}}$ & 3.62 & 19.44 \\
Leaflet area (cm²) @9WAP & $52.94^{\mathrm{ab}}$ & $54.83^{\mathrm{a}}$ & $46.49^{\mathrm{b}}$ & 8.23 & 51.42 \\
No. of primary root branches/plant@9WAP & $6.02^{\mathrm{a}}$ & $6.85^{\mathrm{a}}$ & $5.75^{\mathrm{a}}$ & 1.03 & 6.21 \\
Root length (cm) @9WAP & $57.24^{\mathrm{a}}$ & $54.64^{\mathrm{a}}$ & $53.07^{\mathrm{a}}$ & 7.67 & 54.98 \\
Dry wt. of root/plant (g) @9WAP & $0.644^{\mathrm{a}}$ & $0.724^{\mathrm{a}}$ & $0.693^{\mathrm{a}}$ & 0.084 & 0.691 \\
Shoot dry Wt. (g) @9WAP & $13.93^{\mathrm{a}}$ & $12.79^{\mathrm{a}}$ & $12.08^{\mathrm{a}}$ & 2.97 & 12.93 \\
\hline
\end{tabular}

Values are means of 20 determinations. Means on the same rows with similar alphabets do not differ significantly ( $p<0.05)$ from each other. $D A P$-days after planting; HAP - hours after planting; WAP - weeks after planting. 
Table 4. Yield parameters and yield components of African yam bean at 9 weeks after planting

\begin{tabular}{cccccc}
\hline Yield Parameters & \multicolumn{5}{c}{ Colour Variants } \\
& Black & Brown & Light Grey & LSD $(\mathrm{p}=0.05)$ & Mean \\
\hline No. of root nodules/plant & $21.04^{\mathrm{a}}$ & $22.38^{\mathrm{a}}$ & $23.00^{\mathrm{a}}$ & 3.79 & 22.14 \\
Av. Nodule dry wt. (x10 $\left.0^{-2} \mathrm{~g}\right)$ & $8.59^{\mathrm{a}}$ & $9.38^{\mathrm{a}}$ & $9.08^{\mathrm{a}}$ & 1.87 & 9.02 \\
Days to 50\% flowering & $72.06^{\mathrm{b}}$ & $75.42^{\mathrm{ab}}$ & $78.00^{\mathrm{a}}$ & 5.25 & 75.23 \\
(DAP) & & & & & \\
Days to 50\% maturity & $88.43^{\mathrm{a}}$ & $89.75^{\mathrm{a}}$ & $89.42^{\mathrm{a}}$ & 6.13 & 89.19 \\
(DAP) & $129.98^{\mathrm{a}}$ & $136.79^{\mathrm{a}}$ & $133.12^{\mathrm{a}}$ & 8.11 & 133.29 \\
No. of flowers/plant & $4.64^{\mathrm{a}}$ & $5.38^{\mathrm{ab}}$ & $5.98^{\mathrm{a}}$ & 1.61 & 5.35 \\
No. of penduncle/plant & $21.49^{\mathrm{a}}$ & $20.63^{\mathrm{a}}$ & $20.72^{\mathrm{a}}$ & 2.93 & 20.95 \\
Penduncle length (cm) & $18.68^{\mathrm{a}}$ & $16.43^{\mathrm{a}}$ & $19.63^{\mathrm{a}}$ & 3.26 & 18.25 \\
Pod length (cm) & $4.008^{\mathrm{a}}$ & $3.38^{\mathrm{b}}$ & $3.27^{\mathrm{b}}$ & 0.18 & 3.44 \\
No. of pod/penduncle & $22.03^{\mathrm{a}}$ & $19.69^{\mathrm{a}}$ & $20.73^{\mathrm{a}}$ & 3.39 & 20.82 \\
No. of pods/plant & $12.29^{\mathrm{ab}}$ & $13.28^{\mathrm{a}}$ & $11.88^{\mathrm{b}}$ & 1.38 & 12.48 \\
No.of seeds/pods & $279.13^{\mathrm{a}}$ & $266.37^{\mathrm{a}}$ & $248.02^{\mathrm{b}}$ & 18.16 & 264.23 \\
No. of seeds/plant & $10.02^{\mathrm{a}}$ & $9.01^{\mathrm{a}}$ & $8.49^{\mathrm{a}}$ & 2.06 & 9.17 \\
100 seed wt $(\mathrm{g})$ & $1542.28^{\mathrm{a}}$ & $1304.23^{\mathrm{b}}$ & $1259.97^{\mathrm{b}}$ & 110.06 & 1368.82 \\
Grain yield $(\mathrm{kg} / \mathrm{ha})$ & & & & \\
\hline
\end{tabular}

Values are means of 20 determinations. Means on the same rows with similar alphabets do not differ significantly ( $p<0.05)$ from each other. DAP - days after planting.

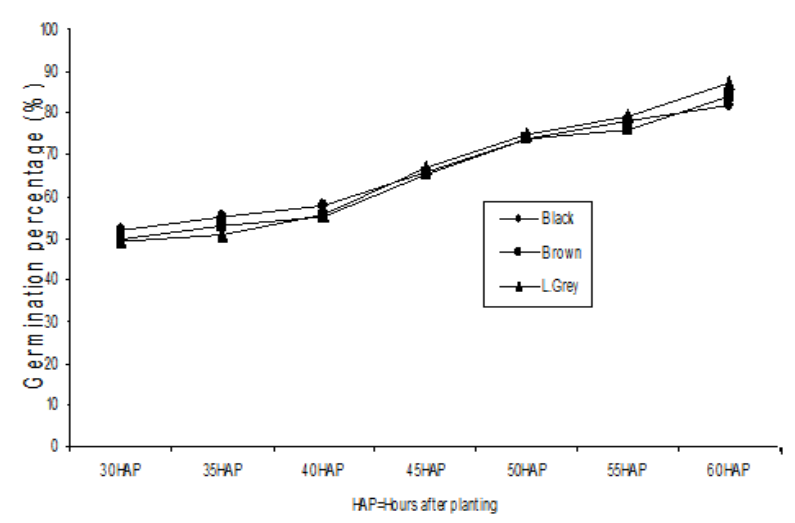

Figure 1. Comparison of percentage of germination of the three colour variants of African yam bean grown in Edo State

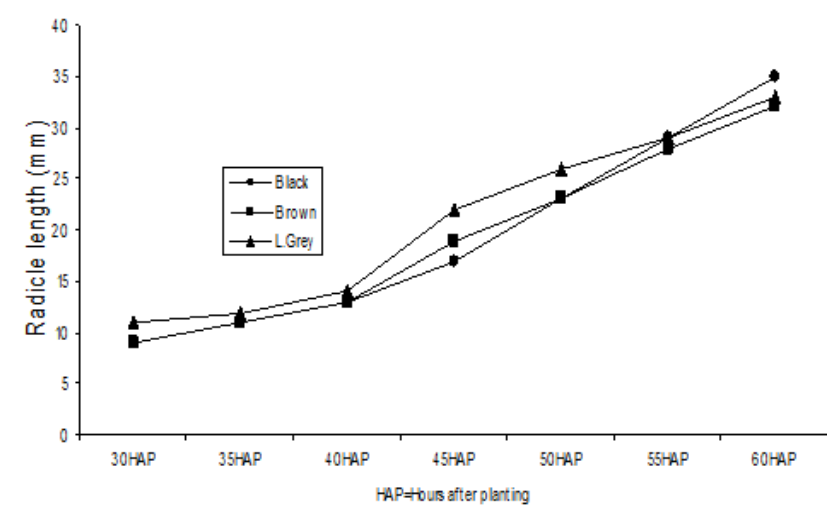

Figure 2. Comparison of radicle lenths of the three colour variants of African yam bean grown in Edo State

Average nodule dry weight at 9 weeks after planting (WAP) was $9.02 \times 10^{-2} \mathrm{~g}$ (Table 4 ), where as there were 22.14 root nodules per African yam bean. These results did not significantly differ among the three colour variants. This agrees with the previous report of Ikhajiagbe et al.[9] that average number of nodules per plant was 21.38 and $9.02 \mathrm{x}$ $10^{-2} \mathrm{~g}$ as nodule weight of African yam bean. There was significant delay in attaining $50 \%$ flowering in the light grey bean variety (78 DAP), compared to the black bean type (72.06 DAP). Mean number of days to $50 \%$ flowering was 75.23 DAP. No significant change in $50 \%$ maturity was however recorded (mean 89.19 DAP).

Grain yield per hectare was significantly $(\mathrm{p}<0.05)$ highest in the black variant $(1542.28 \mathrm{~kg})$, compared to the brown variant $(1304.23 \mathrm{~kg})$ and the light grey variant $(1259.97 \mathrm{~kg})$. The average grain yield comparative among the three colour variants was $1368.82 \mathrm{~kg} / \mathrm{ha}$, and this did not compare significantly with the value $(1057.55 \mathrm{~kg} / \mathrm{ha})$ previously obtained by Ikhajiagbe et al.[20] and the $3025 \mathrm{~kg}$ dry seeds per hectare obtained by Okigbo[21]. Ezeuh[22] and Okoye and Ene-Obong[23] previously reported that the black variant had higher number of pods and seeds. No significant variability was recorded in the nutritional composition of the various colour variants of African yam bean seeds (Table 5). However, the black colour variant was significantly higher in total ash $(3.17 \%)$ compared to average value $(2.98 \%)$. Average crude protein content was $23.59 \%$, crude fibre was $5.17 \%$, and ether extract was $7.76 \%$ while dry matter was $87.86 \%$.

Table 5. Nutritional composition of seeds of African yam bean

\begin{tabular}{cccccc}
\hline $\begin{array}{c}\text { Parameters } \\
(\%)\end{array}$ & \multicolumn{5}{c}{ Colour Variants } \\
& Black & Brown & $\begin{array}{c}\text { Light } \\
\text { Grey }\end{array}$ & $\begin{array}{c}\text { LSD } \\
(\mathrm{p}=0.05)\end{array}$ & Mean \\
\hline Dry matter & $87.79^{\mathrm{a}}$ & $88.51^{\mathrm{a}}$ & $87.36^{\mathrm{a}}$ & 4.21 & 87.86 \\
Crude protein & $24.06^{\mathrm{a}}$ & $23.59^{\mathrm{a}}$ & $23.14^{\mathrm{a}}$ & 1.68 & 23.59 \\
Crude fibre & $5.20^{\mathrm{a}}$ & $5.33^{\mathrm{a}}$ & $4.98^{\mathrm{a}}$ & 0.43 & 5.17 \\
Total ash & $3.17^{\mathrm{a}}$ & $2.79^{\mathrm{b}}$ & $2.98^{\mathrm{ab}}$ & 0.38 & 2.98 \\
Ether extract & $7.89^{\mathrm{a}}$ & $8.13^{\mathrm{a}}$ & $7.28^{\mathrm{a}}$ & 1.23 & 7.76 \\
\hline
\end{tabular}

Values are means of 20 determinations. Means on the same rows with similar alphabets do not differ significantly $(p<0.05)$ from each other.

The broad based heritability estimates, genetic advance and genetic gain of the yield parameters in all three variants have been presented in Table 6 . The heritability estimates $66.85-97.95 \%$ were moderate to high in all colour variants. Genetic gain ranged from $15.31-46.18$. 
Table 6. Genetic parameters of yield parameters of the three variants of African yam beans

\begin{tabular}{cccccccc}
\hline Character & Mean & $\begin{array}{c}\text { Phenotypic } \\
\text { Variance } \\
\left(\delta^{2} \mathrm{ph}\right)\end{array}$ & $\begin{array}{c}\sqrt{ }\left(\delta^{2} \mathrm{ph}\right) \\
\text { or } \delta \mathrm{ph}\end{array}$ & $\begin{array}{c}\text { Genotypic } \\
\text { Variance } \\
\left(\delta^{2} \mathrm{~g}\right)\end{array}$ & $\begin{array}{c}\text { Heritability } \\
(\%)\end{array}$ & $\begin{array}{c}\text { Genetic } \\
\text { Advance }\end{array}$ & $\begin{array}{c}\text { Genetic } \\
\text { Gain }\end{array}$ \\
\hline $\begin{array}{c}\text { Shoot height } \\
(\mathrm{cm})\end{array}$ & 121.68 & 267.22 & 16.35 & 202.39 & 75.74 & 25.50 & 20.96 \\
$\begin{array}{c}\text { No. of } \\
\text { leaves/plant }\end{array}$ & 19.44 & 4.69 & 2.17 & 4.12 & 87.91 & 3.91 & 20.12 \\
$\begin{array}{c}\text { Pod length (cm) } \\
\quad \text { No. of }\end{array}$ & 18.25 & 20.17 & 4.49 & 18.37 & 91.10 & 8.43 & 46.18 \\
$\begin{array}{c}\text { pods/plant } \\
\text { No. of }\end{array}$ & 20.82 & 5.38 & 2.32 & 3.59 & 66.85 & 3.19 & 15.31 \\
$\begin{array}{c}\text { seeds/pod } \\
\text { Grain yield (g) }\end{array}$ & 12.48 & 2.05 & 1.43 & 1.54 & 75.02 & 2.02 & 16.18 \\
\hline
\end{tabular}

Although the vast genetic and economic potentials of African yam bean have been recognized, especially in reducing malnutrition among Africans, the crop has not received adequate research attention. Up till now, it is classified as a neglected underutilized species. Devos et al.[24] stressed that the danger of losing essential germplasm hangs over all cultivated food crop species in tropical Africa, especially those not receiving research attention. The quantity and availability of African yam bean germplasm is decreasing with time. At one time, Klu et al.[25] had speculated that the crop was nearing extinction; its inherent ability to adapt to diverse environments[26] may have been responsible for its continual existence and survival. Nevertheless, scientists think that the genetic resources of African yam bean may have been undergoing gradual erosion. The International Institute for Tropical Agriculture (IITA) keeps over 80 accessions of the crop, but otherwise, its conservation in $\mathrm{Ni}$ geria is very poor and access to its genetic resources is severely limited. Improvement of the crop is possible only when the intraspecific variability of the large genetic resources of the species is ascertained. The present study showed that of the three colour variants of African yam bean, the black colour variant was significantly better when considered for agronomic purposes, particularly given the fact that it was highest in shoot growth and overall grain yield, compared to both brown and light grey variants.

\section{REFERENCES}

[1] Ikhajiagbe, B. (2003). African Yam Bean in Nigeria: the stone that the builders rejected. Raw Materials Digest 1 (1): $2-4$.

[2] Bates, D.M. (1985). Plant utilization: patterns and prospect. Economic Botany 39: 241265.

[3] NAS (1979). Tropical Legumes: Resources for the Future. National Academy of Sciences, Washington D.C. pp. 331.

[4] Tindall, H.D. (1983). Vegetables in the Tropics. II. AVI, Westport CT. 323p.

[5] Apata, D.F. and Ologhobo, A.D. (1990). Some aspects of biochemistry and nutritive value of African yam bean seed
(Sphenostylis stenocarpa). Food Chemistry 36: 271-280.

[6] Sinha, S.K. (1977). Food legumes: distribution adaptability and biology of yield FAO Plant Production and Protection Paper 3. FAO. Rome.

[7] Olayide, S.O. (1982). Food and Nutrition Crisis in Nigeria. Ibadan University Press, Ibadan. 112p.

[8] ISTA (1976). International Rules for Seed Testing Association. Norway Seed Science Technology 4:2-49

[9] Ikhajiagbe, B., Mgbeze, G.C. and Folu M. Dania Ogbe (2007a). Responses of Sphenostylis stenocarpa (Hochst Ex A. Rich) Harms (African yam bean) to salinity stress I: Germination and vegetative growth. Nigerian Journal of Botany 20(1): 69-82.

[10] Prado, F.E., Boero, C., Gallardo, M. and Gonzalez, J.A. (2000). Effect of $\mathrm{NaCl}$ on germination, growth, and sugar content in Chenopodium quinoa Wild seeds. Botanical Bulletin of Academia Sinica 41: 27-34.

[11] Okeleye, K; Ariyo, O.J; and Olowe, V.I. (1999). Evaluation of early and medium duration cowpea cultivars for agronomic and grain yield. Nigeria Agricultural Journal 30:1-11.

[12] Eze, J.M.O. (1965). Studies on growth regulations, salt uptake and translocation. Ph.D thesis, University of Durham, U.K., p. 31 .

[13] Holden, M. (1965). Chlorophylls. In: Chemistry and Biochemistry of Plant Pigments, Goodwin TW (ed.), Academic Press London; pp. 462-488.

[14] IBPGR and ICRISAT (1993). Descriptors for Pigeon Pea[Cajanus cajan (L.) Millsp.]. International Board for Plant Genetic Resources Secretariat, Rome, and International Crops Research Institute for the Semi-Arid Tropics, India. $31 \mathrm{p}$.

[15] AOAC (1975). Official Methods of Analysis. $12^{\text {th }}$ edition. Association of Official Analytical Chemists. Washington D.C. 2. 049. 7. 016.

[16] IITA (1979). Selected Methods for Soil and Plant Analysis. International Institute for Tropical Agriculture, IITA Monograph 1.

[17] Beridize, R.K., Hanelt, P., and Kruse, J. (1982). Report of a travel to the Georgian SSR 1981 for the collection of indigenous materials of cultivated plant. Kulfurplanze, $p p$ 203-213. 
[18] Valio, I.F.M. (1986). The role of the seed coat in any stages of soybean germination. Biol. Plant 28: 258-264.

[19] Duke, S.H. and Kakefuda, G. (1981). Role of testa in preventing cellular rupture during imbibition of legume seeds. Plant Physiology 67: 449-456.

[20] Ikhajiagbe, B., Mgbeze, G.C. and Folu M. Dania Ogbe. (2007b) Responses of Sphenostylis stenocarpa (Hochst ex a. Rich) Harms (African yam bean) to salinity stress ii: Yield, yield components, and chemical composition. Nigerian Journal of Botany 20(1): 83-92.

[21] Okigbo, B.N. (1973). Introducing the yam bean (Sphenostylis stonocarpa. Hochest ex A. Rich) Hams Proc. The first ITTA Grain Legume Improvement Workshop, 29 Oct-2 Nov. 1973., Ibadan, Nigeria.

[22] Ezeuh, M.I. (1984). African yam bean as a crop in Nigeria. World Crop 36b: 199-200.
[23] Okoye, F.I. and Ene-Obong, E.E. (1992). Genetic variability and correlation studies in African yam bean (Sphenostylis stenocarpa). Nigerian Journal of Botany 5:75-83.

[24] Devos, P., Wilson, G.F., and Delanghe, E. (1980). Plantain: Genetic resources and potential in Africa. In: Doku, E.V. (ed) Genetic Resource of Legumes in Africa. Proceedings of a workshop jointly organized by the Association for the Advancement of Agricultural Science in Africa and IITA, Ibadan, Nigeria, 4-6 January 1978. Pp 150-157

[25] Klu, G.Y.P., Amoatey, H.M., Bansa, D., and Kumaga, F.K. (2001). Cultivation and uses of African yam bean (Sphenostylis stenocarpa) in the Volta Region of Ghana. The Journal of Food Technology in Africa 6:74-77.

[26] Schippers, R.R. (2000). African indigenous vegetables: An overview of the cultivated species. Natural Resources Institute/ ACP-EU Technical Centre for Agricultural and Rural Cooperation, Chatham, UK. pp. 89-98. 